\title{
全球降水観測（GPM）計画の現状
}

\section{Status of global precipitation measurement (GPM) mission}

\author{
五十嵐 保* ・遠藤 貴宏* \\ Tamotsu IGARASHI and Takahiro ENDO
}

\begin{abstract}
GPM (global precipitation measurement) core observatory was launched by H-IIA-F23 rocket on 28 February, 2014 successfully. The first light images by mission instruments; DPR (dual-frequency precipitation radar) and GMI (GPM microwave imager) were released on 25 March, 2014 by JAXA/NASA, which are verifying qualitative precipitation intensity in vertical and horizontal distribution. This review is describing overview of GPM core observatory with DPR, GMI, status of GPM constellation satellites, and GSMaP (global satellite mapping of precipitation).
\end{abstract}

\section{1.はじめに}

日米協力により, 宇宙航空研究開発機構 (JAXA) 及 び米国航空宇宙局（NASA）の共同運用中の熱帯降雨 観測衛星 ${ }^{1)}$ (TRMM : tropical rainfall measurement mission) は, 衛星からのレーダによる世界初の降雨観 測衛星であり，1997年11月の打上げ以来，2014年現在 まで，当初の設計寿命を大幅に超え観測を継続してい る。

2014年 2 月28日, 第二世代の全球降水観測（GPM : global precipitation measurement）計画 ${ }^{3) の 中 心 と な ~}$ る GPM 主衛星が H-IIA ロケット23号機により打上 げに成功した。3 月25日には初画像が公開され，その 後初期の運用が進みつつあるが, 降水観測領域を広げ, 観測頻度，降水量観測精度の向上などが検証され，本 格的な運用に移行する計画である。

GPM 計画は, 主衛星を中心に複数の副衛星群に よって構成されるコンステレーション（星座）を編成 し観測する計画であり, 主衛星の開発・打上げ・運用 を日米で分担し，更に複数の国々の宇宙機関により打 ち上げられる衛星が参加し, 全球観測データの相互利 用協力の進展が進みつつある。

その結果, 気候変動, 地球環境, 生態系の安定的な

*一般財団法人リモート・センシング技術センター

「写真測量とリモートセンシング」VOL. 53, NO. 3, 2014
保全に不可欠な水，集中豪雨による洪水や日照りによ る旱䰠などの気象災害の要因となる，水の時間空間分 布の変動に関する情報利用が期待される。

\section{GPM のシステム構成}

GPM 主衛星は, 図 1 の外観図に示すように, アク ティブ・フェイズド・アレイ方式の二周波降水レーダ (DPR : dual-frequency precipitation radar) 及び多 周波マイクロ波放射計 (GMI: GPM microwave imager)をミッション機器として搭載している。DPR を地球指向面 (衛星下部) に搭載する一方, GMI を深 宇宙指向面に搭載し, 主反射鏡の回転により地球大気 を走査し, 降水強度の 3 次元分布を観測する。

観測ミッションを支える衛星バス部は, 太陽電池ア レイ, 推進モジュール, リアクションホイール, アビ オニクス, スター・トラッカー, 追跡・データ中継衛 星を介して地上局と観測データや衛星のハウスキーピ ングのためのテレメトリ，コマンドを送受信する高利 得アンテナから構成されている。

GPM 主衛星の軌道（表 1 ） は, 軌道傾斜角 $65^{\circ}$ で, TRMM の軌道傾斜角 $35^{\circ} よ り も$ 高緯度まで観測が可 能となり, 熱帯, 中緯度地域を越え, 北は北極圈に近 いグリーンランド南端, 南は南極半島の先端まで観測 範囲が拡大する。また，太陽非同期軌道をとることで， 降水の日変化を捉える。 


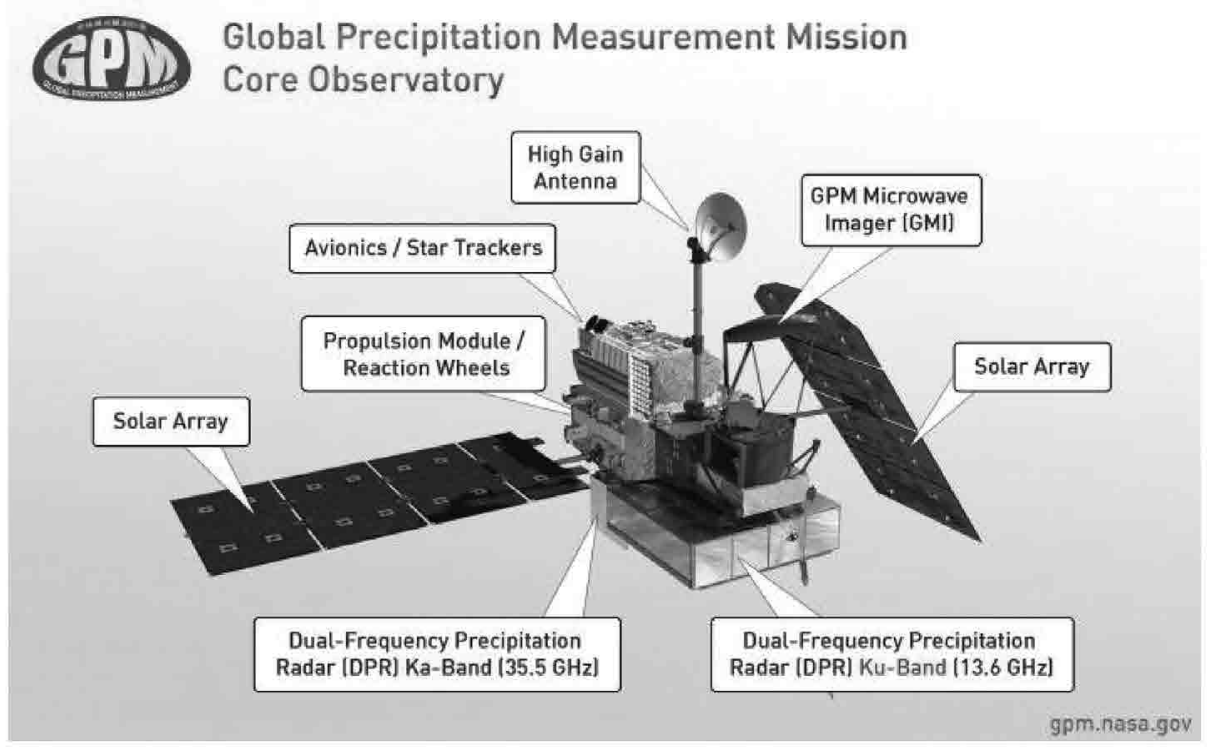

図 1 全球降水観測 (GPM) 主衛星（GPM Core Observatory）出典：NASA http://pmm.nasa.gov/image-gallery/gpm-core-observatory-diagram-0

DPR は TRMM 搭載の降雨レーダ (PR： precipitation radar) と同じ周波数 $13.6 \mathrm{GHz}$ のレーダに, 周波 数 $35.5 \mathrm{GHz}$ のレーダを新たに追加したものである。 GMI も TRMM 搭載マイクロ波観測装置 (TMI) と同 じ 9 つの周波数帯に加えて, 4 つの高周波チャンネル （166及び183GHz 帯）を追加した（表 2)。

DPRの走查幅は, $13.6 \mathrm{GHz}$ レーダでは約 $245 \mathrm{~km}$ ，

表 1 全球降水観測（GPM）計画主衛星の軌道

\begin{tabular}{|l|l|}
\hline \multicolumn{1}{|c|}{ パラメータ } & \multicolumn{1}{c|}{ 数值 } \\
\hline \hline 軌道傾斜角 & $65^{\circ}$ \\
\hline 平均軌道長半径 & $6776.14 \mathrm{~km}$ \\
\hline 高度制御ボックス & $\pm 1 \mathrm{~km}$ \\
\hline 離心率 & 0.00010 \\
\hline
\end{tabular}

$35.5 \mathrm{GHz}$ レーダでは約 $120 \mathrm{~km}$ である（図 2 ）。両者の 走查幅が重なる部分で同時観測し高精度化する。一方, GMI は円錐面に沿って地表面を走查することにより， 広い走查幅約 $800 \mathrm{~km}$ が得られる。

GPM 主衛星の役割は，レーダとマイクロ波放射計 の同時観測により精度向上を図り, GPM 副衛星群を 含めたコンステレーションの降水観測精度を向上させ ることにある。

GPM の DPR では TRMM の PR と同じ KuPR (13.6GHz) 帯で高感度化し, KaPR $(35.5 \mathrm{GHz})$ 帯レー ダを加え, 観測される降雨強度の限界值は, PR が 0.7 $\mathrm{mm} / \mathrm{h}$ であるのに対し, DPR は, KuPR が $0.5 \mathrm{~mm} / \mathrm{h}$, $\mathrm{KaPR}$ が $0.2 \mathrm{~mm} / \mathrm{h}$ と高感度化し, 弱い雨の観測も可 能となる (表 3 )。

表 2 全球降水観測（GPM）計画主衛星の搭載センサの主要諸元

\begin{tabular}{|c|c|c|}
\hline 搭載センサ & 観測周波数帯 & 機関 \\
\hline \multirow{2}{*}{$\begin{array}{l}\text { 二周波降水レーダ } \\
\text { Dual-frequency precipitation radar } \\
\text { (DPR) }\end{array}$} & $\mathrm{Ku}$ 帯（13.6GHz） & 宇宙航空研究開発機構 \\
\hline & $\mathrm{Ka}$ 帯（35.5GHz） & 宇宙航空研究開発機構 \\
\hline $\begin{array}{l}\text { GPM マイクロ波イメージャ } \\
\text { GPM microwave imager (GMI) }\end{array}$ & $\begin{array}{l}\text { TRMM マイクロ波イメージャ（TMI） } \\
\text { の観測波長チャンネルに高周波数 } 4 \text { チャ } \\
\text { ンネル (166及び183GHz 帯) 追加 }\end{array}$ & 米国 \\
\hline
\end{tabular}




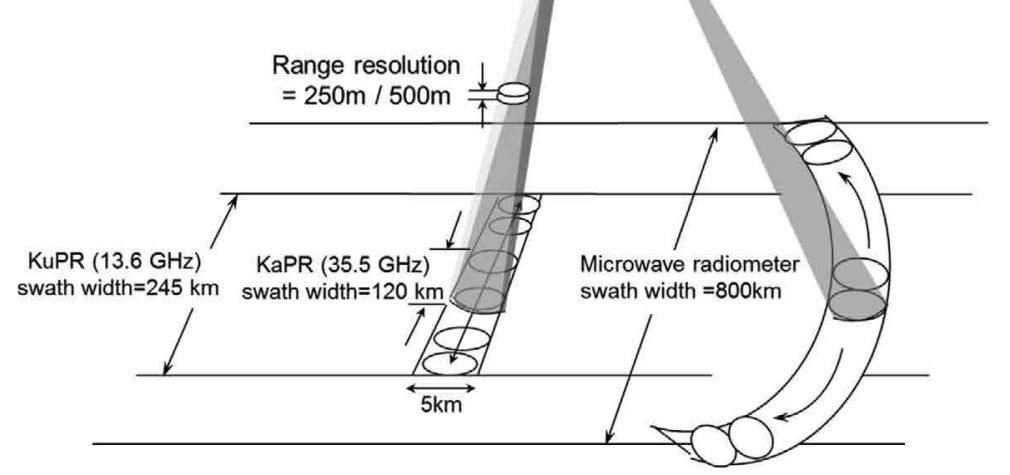

図 2 GPM 搭載 DPR（KuPR, KaPR）及び GMI の地表面観測ジオメトリ及び分解能 出典：JAXA ${ }^{3)}$

表 3 二周波降水レーダ（DPR）の主要諸元

\begin{tabular}{|c|c|c|}
\hline パラメータ & $\mathrm{Ku}$ 带降水レーダ & Ka 帯降水レーダ \\
\hline 観測幅 & $245 \mathrm{~km}$ & $120 \mathrm{~km}$ \\
\hline レンジ（鉛直）分解能 & $250 \mathrm{~m}$ & $250 / 500 \mathrm{~m}$ \\
\hline 水平分解能（直下点） & $5.2 \mathrm{~km}$ （軌道高度 $407 \mathrm{~km} ）$ & $5.2 \mathrm{~km}$ （軌道高度 $407 \mathrm{~km} ）$ \\
\hline ビーム幅 & $0.71^{\circ}$ (中心ビーム) & $0.71^{\circ}$ (中心ビーム) \\
\hline 送信機 & 128固体増幅器 & 128固体増幅器 \\
\hline 送信電力（ピーク） & $1012.0 \mathrm{~W}$ & $146.5 \mathrm{~W}$ \\
\hline パルス繰返し周波数 & $4000 \sim 4500 \mathrm{~Hz}$ & $4000 \sim 4500 \mathrm{~Hz}$ \\
\hline パルス幅 & $1.6 \mu \mathrm{sec}$ 幅 2 パルス & $\begin{array}{l}1.6 \mu \mathrm{sec} \text { 幅 } 2 \text { パルス (マッチド・ビーム走査) } \\
3.2 \mu \mathrm{sec} \text { 幅 } 2 \text { パルス (飛び越し走查) }\end{array}$ \\
\hline ビーム数 & 49 & $\begin{array}{l}49(25 \text { (マッチド・ビーム) 及び24（飛び越 } \\
\text { し走查) })\end{array}$ \\
\hline 観測降雨強度（限界） & $0.5 \mathrm{~mm} / \mathrm{h}$ & $0.2 \mathrm{~mm} / \mathrm{h}$ \\
\hline ビームマッチング・エラー & \multicolumn{2}{|l|}{$1000 \mathrm{~m}$ 未満 } \\
\hline 観測高度範囲 & \multicolumn{2}{|c|}{ 地表から $19 \mathrm{~km} （$ 衛星直下点近傍ではー $5 \mathrm{~km}$ から） } \\
\hline ダイナミック・レンジ & \multicolumn{2}{|c|}{ システム雑音レベル以下 $-5 \mathrm{~dB}$ から最大表面エコーレベル公称值以上 $+5 \mathrm{~dB}$} \\
\hline 受信電力精度 & \multicolumn{2}{|l|}{$+/-1 \mathrm{~dB}$} \\
\hline 走査角（観測モード） & $\pm 17^{\circ}$ 軌道直交方向 & $\pm 8.5^{\circ}$ 軌道直交方向 \\
\hline 送信周波数 & 13.597及び13.603GHz & 35.547及び $35.553 \mathrm{GHz}$ \\
\hline 帯域幅 & \multicolumn{2}{|l|}{$14 \mathrm{MHz}$} \\
\hline 最大重量 & $472 \mathrm{~kg}$ & $336 \mathrm{~kg}$ \\
\hline 電力（最大值） & $446 \mathrm{~W}$ (軌道平均) & $344 \mathrm{~W}$ (軌道平均) \\
\hline 科学データレート (最大値) & 109kbps（KuPR 及び KaPR の合計190kbps） & 81kbps（KuPR 及び KaPR の合計190kbps） \\
\hline $\begin{array}{l}\text { 八ウスキーピング } \\
\text { データレート (公称值) }\end{array}$ & \multicolumn{2}{|l|}{$1 \mathrm{kbps}$} \\
\hline
\end{tabular}


表 4 二周波降水レーダ（DPR）のレベル 1 プロダクトレベルの定義

\begin{tabular}{|c|c|c|c|}
\hline プロダクト & 定義 & 運用モード & 備考 \\
\hline \multirow[t]{3}{*}{$\begin{array}{l}\mathrm{KuPR} \\
\text { レベル } 1 \\
\mathrm{KaPR} \\
\text { レベル } 1\end{array}$} & \multirow{3}{*}{$\begin{array}{l}\text { 受信電力に次の処理を施 } \\
\text { したプロダクトレベル：} \\
\text { ラジオメトリック補正 ; } \\
\text { ミッシングデータ処理 ; } \\
\text { 走査時間補正 ; 時間, 緯 } \\
\text { 度経度, 各レンジビン内 } \\
\text { の各走査データピースの } \\
\text { 高度による幾何学計算 }\end{array}$} & $\begin{array}{l}\text { 通常観測モード } \\
\text { 外部校正モード } \\
\text { 固 体 電力増幅器 (SSPA： solid state } \\
\text { power amplifier) 運用解析モード } \\
\text { 低雑音増幅器 (LNA：low noise ampli- } \\
\text { fier) 運用解析モード }\end{array}$ & $\begin{array}{l}\text { 受信電力プロファイル } \\
\text { 走査及びレンジビンの位置情報 } \\
\text { 品質情報 } \\
\text { 校正データ }\end{array}$ \\
\hline & & 内部校正モード & $\begin{array}{l}\text { 科学テレメトリの受信カウント值 } \\
\text { 走査及びレンジビンの位置情報 } \\
\text { 校正データ }\end{array}$ \\
\hline & & $\begin{array}{l}\text { スタンバイ・モード } \\
\text { ヘルスチェック・モード }\end{array}$ & ミッシングデータ情報 \\
\hline
\end{tabular}

表 5 二周波降水レーダ（DPR）のレベル 2, レベル 3 プロダクトレベルの定義

\begin{tabular}{|c|c|c|}
\hline プロダクト & 定義 & 備考 \\
\hline KuPR レベル 2 & \multirow{3}{*}{$\begin{array}{l}\text { レベル } 1 \text { プロダクトを入力としレベル } \\
2 \text { アルゴリズムにより計算された降水 } \\
\text { に関する様々な物理量を含むプロダク } \\
\text { ト (地表面のレーダ断面積, 降水タイ } \\
\text { プ, ブライトバンド高度, 減衰補正済 } \\
\text { レーダ反射因子, 降水強度等)。 }\end{array}$} & $\begin{array}{l}\mathrm{KuPR}(\mathrm{Ku} \text { バンド降水レーダ }) \text { レベル } 2 \text { プロダクト } \\
\text { 周波数 } 13.6 \mathrm{GHz}\end{array}$ \\
\hline KaPR レベル 2 & & $\begin{array}{l}\mathrm{KaPR}(\mathrm{Ka} \text { バンド降水レーダ }) \text { レベル } 2 \text { プロダクト } \\
\text { 周波数 } 35.5 \mathrm{GHz}\end{array}$ \\
\hline DPR レベル 2 & & DPR（二周波降水レーダ）プロダクト \\
\hline $\begin{array}{l}\text { 二周波降水レーダ } \\
\text { レベル } 3 \text { (日平均) }\end{array}$ & \multirow{2}{*}{$\begin{array}{l}\text { レベル } 1 \text { 又はレベル } 2 \text { プロダクトをイ } \\
\text { ンプットデータとし時空間統計処理に } \\
\text { より生成されるプロダクト } \\
\text { (緯度 } 5^{\circ} \times \text { 経度 } 5^{\circ} \text { 又は緯度 } 0.25^{\circ} \times \text { 経 } \\
\left.\text { 度 } 0.25^{\circ} \text { 格子の平均降水強度 }\right)\end{array}$} & 日平均降水強度值 \\
\hline $\begin{array}{l}\text { 二周波降水レーダ } \\
\text { レベル } 3 \text { (月平均) }\end{array}$ & & 月平均降水強度值 \\
\hline
\end{tabular}

\section{3.プロダクトレベルの定義}

二周波降水レーダ (DPR) のレベル 1 プロダクトレ ベルの定義を表 4 に，レベル 2 ，レベル 3 プロダクト レベルの定義を表 5 に示す。

\section{4. 初画像公開}

全球降水観測 (GPM) 計画は, GPM 主衛星と副衛 星群によって, 一日に複数回, 地球全体の降水（降雨 及び降雪)を観測する。GPM 計画の要となる GPM 主 衛星は, JAXA が情報通信研究機構(NICT) と共同で 開発した二周波降水レーダ (DPR) と，NASA が開発 した GPM マイクロ波放射計 (GMI) の二つのミッ ション機器を搭載している。DPR（図 $3 ， 4$ ）は 3 月 9 日より，GMI（図5) は3 月5 日より, それぞれ初 期チェック・アウトを開始し, 本期間中に取得したデー 夕から試験的に処理を行い初画像として一般公開して いる。
初期チェック・アウト終了後, ミッション機器の校 正, 観測デー夕の定量的な精度検証・評価確認を行っ た後，打上げ約半年後から，GPM 主衛星が観測する データの一般利用者による入手を可能とする計画であ る。

\section{GPM コンステレーションの現状}

GPM 主衛星を中心に GPM 副衛星群により構成さ れる，GPM コンステレーション3)の現状 (2014年 1 月 13 日現在) を図 6 に示す。GPM 副衛星群の搭載センサ 及び開発・打上げを実施した宇宙機関を表 6 に示す。

JAXA は, NASA と共同開発し打上げ, 初期運用を 開始した GPM 主衛星及び1997年打上げ以降継続運用 中の TRMM の他, 2012年 5 月に打上げた第一期水循 環変動観測衛星「しずく」(GCOM-W1) の 3 機がコン ステレーションに参加している。この他, 困 6 , 表 6 に示す通り, 米国航空宇宙局 (NASA), 米国海洋大気 


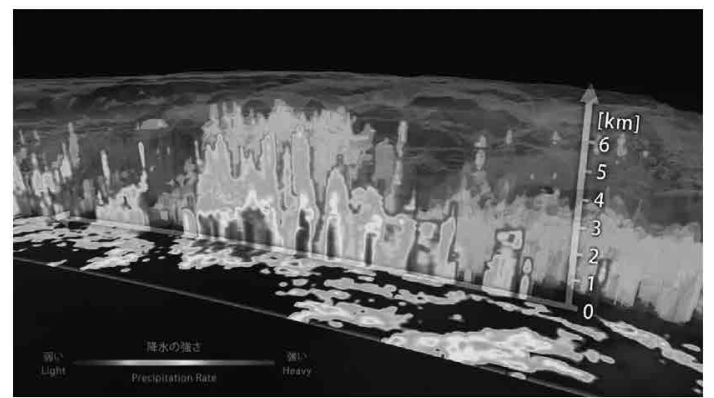

図 3 二周波降水レーダ (DPR) による降水の 3 次元分布図 画像クレジット：JAXA/NASA

http://www.jaxa.jp/press/2014/03/20140325_ gpm_j. html

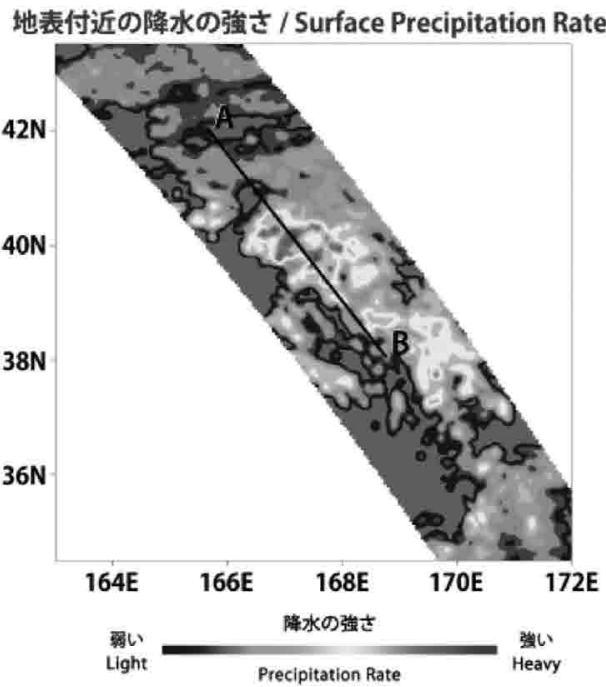

庁 (NOAA)，米国防総省 (DOD)，欧州気象衛星機関 (EUMETSAT)，フランス国立宇宙研究所 (CNES) 及びインド宇宙研究機関 (ISRO) が共同開発した衛星 が参加している。

\section{6.世界の雨分布速報 (GSMaP)}

世界の雨分布速報 (GSMaP : global satellite mapping of precipitation) は，世界の雨分布を準リアルタ イム（観測から約 4 時間遅れ）で 1 時間ごとに複数の 衛星（TRMM TMI, Aqua AMSR-E, GCOM-W1 AMSR2, DMSP SSM/I, DMSP SSMIS, NOAA-19
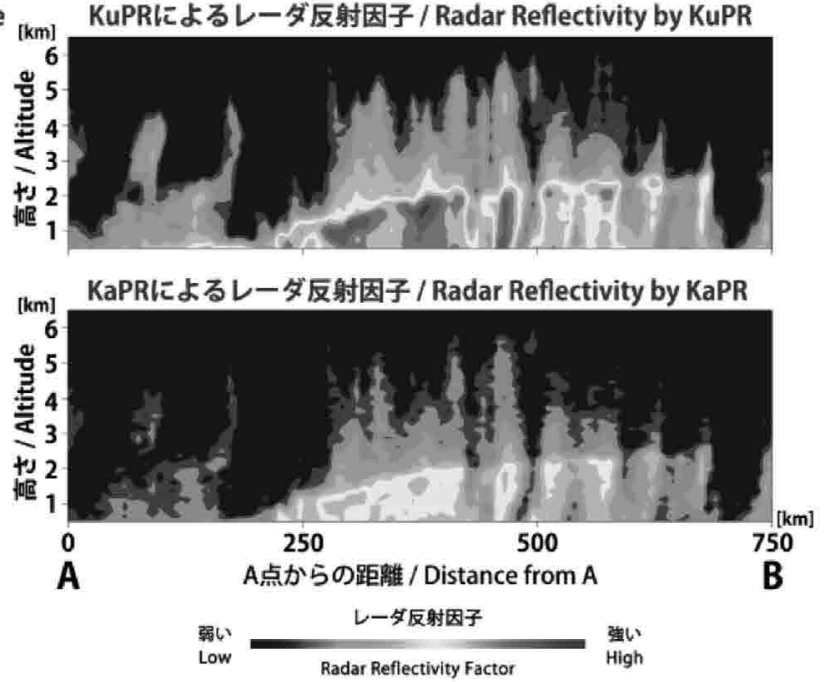

図 4 二周波降水レーダ（DPR）の KuPR（周波数：13.6GHz）のレーダ反射因子及び KaPR（周波数：35.5GHz）のレー ダ反射因子の違い 画像クレジット：JAXA/NASA

http://www.satnavi.jaxa.jp/gpmdpr_special/movie/movie11.html

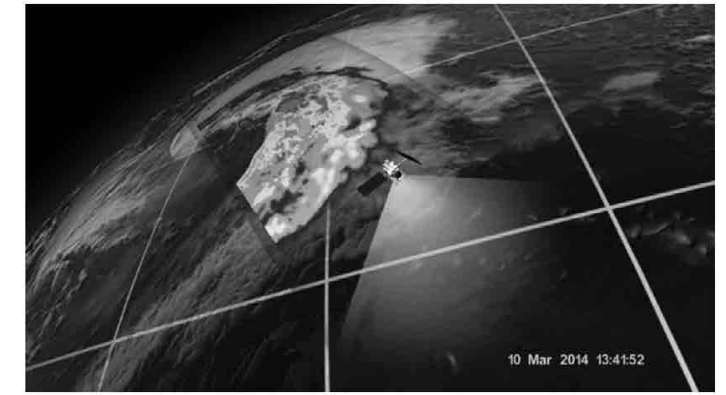

図 5 GPM マイクロ波放射計（GMI）による降水強度平面 分布 画像クレジット：NASA/JAXA

http://www.jaxa.jp/press/2014/03/20140325_ gpm_j.html

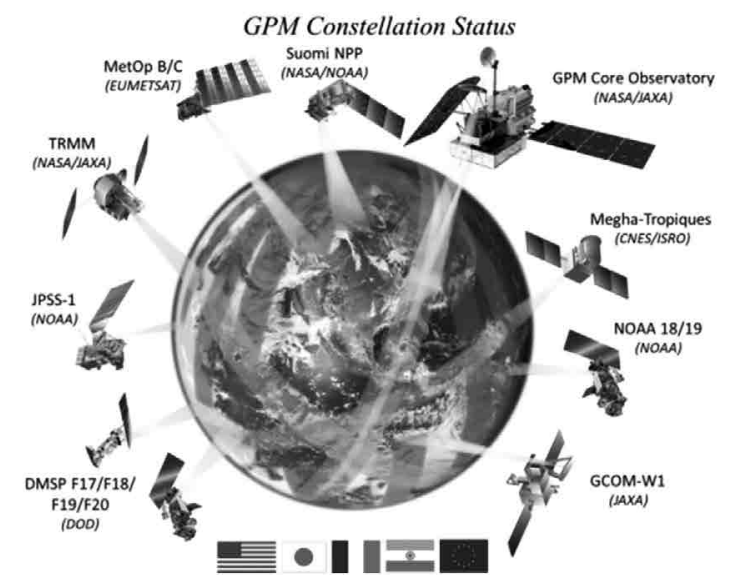

図 6 GPM コンステレーションの状況 (2014年 1 月13日現 在) 出典 : NASA

http://pmm.nasa.gov/image-gallery/gpm-conste llation 
表 6 GPM 副衛星群のセンサ及び宇宙機関

\begin{tabular}{|c|c|c|}
\hline センサ & 衛星 & 機関 \\
\hline $\begin{array}{l}\text { Special Sensor Microwave Imager/ } \\
\text { Sounder (SSMIS) }\end{array}$ & $\begin{array}{l}\text { Defense Meteorological Satellite } \\
\text { Program (DMSP) }\end{array}$ & U.S. Defense \\
\hline $\begin{array}{l}\text { Advanced Microwave Scanning } \\
\text { Radiometer-2 (AMSR-2) }\end{array}$ & $\begin{array}{l}\text { Global Change Observation Mission } \\
\text {-Water } 1(\mathrm{GCOM}-\mathrm{W} 1)\end{array}$ & JAXA \\
\hline $\begin{array}{l}\text { Multi-Frequency Microwave Scan- } \\
\text { ning Radiometer (MADRAS) and } \\
\text { the multi-channel microwave } \\
\text { humidity sounder (SAPHIR) }\end{array}$ & Megha-Tropiques & $\begin{array}{l}\text { Centre National D'Etudies Spatiales } \\
\text { (CNES) of France and the Indian } \\
\text { Space Research Organization } \\
\text { (ISRO) }\end{array}$ \\
\hline $\begin{array}{l}\text { Microwave Humidity Sounder } \\
\text { (MHS) }\end{array}$ & $\begin{array}{l}\text { National Oceanic and Atmospheric } \\
\text { Administration (NOAA)-19 }\end{array}$ & $\begin{array}{l}\text { National Oceanic and Atmospheric } \\
\text { Administration (NOAA) }\end{array}$ \\
\hline MHS & MetOp series & $\begin{array}{l}\text { European Organization for the } \\
\text { Exploitation of Meteorological Sat- } \\
\text { ellites (EUMETSAT) }\end{array}$ \\
\hline $\begin{array}{l}\text { Advanced Technology Microwave } \\
\text { Sounder (ATMS) }\end{array}$ & $\begin{array}{l}\text { National Polar-orbiting Opera- } \\
\text { tional Environmental Satellite Sys- } \\
\text { tem (NPOESS) Preparatory Project } \\
\text { (NPP) }\end{array}$ & US \\
\hline ATMS & Joint Polar Satellite System (JPSS) & NOAA-NASA \\
\hline Microwave imager & $\begin{array}{l}\text { Defense Weather Satellite System } \\
\text { (DWSS) }\end{array}$ & Defense \\
\hline
\end{tabular}

\section{GSMaP: Global Satellite Mapping of Precipitation}

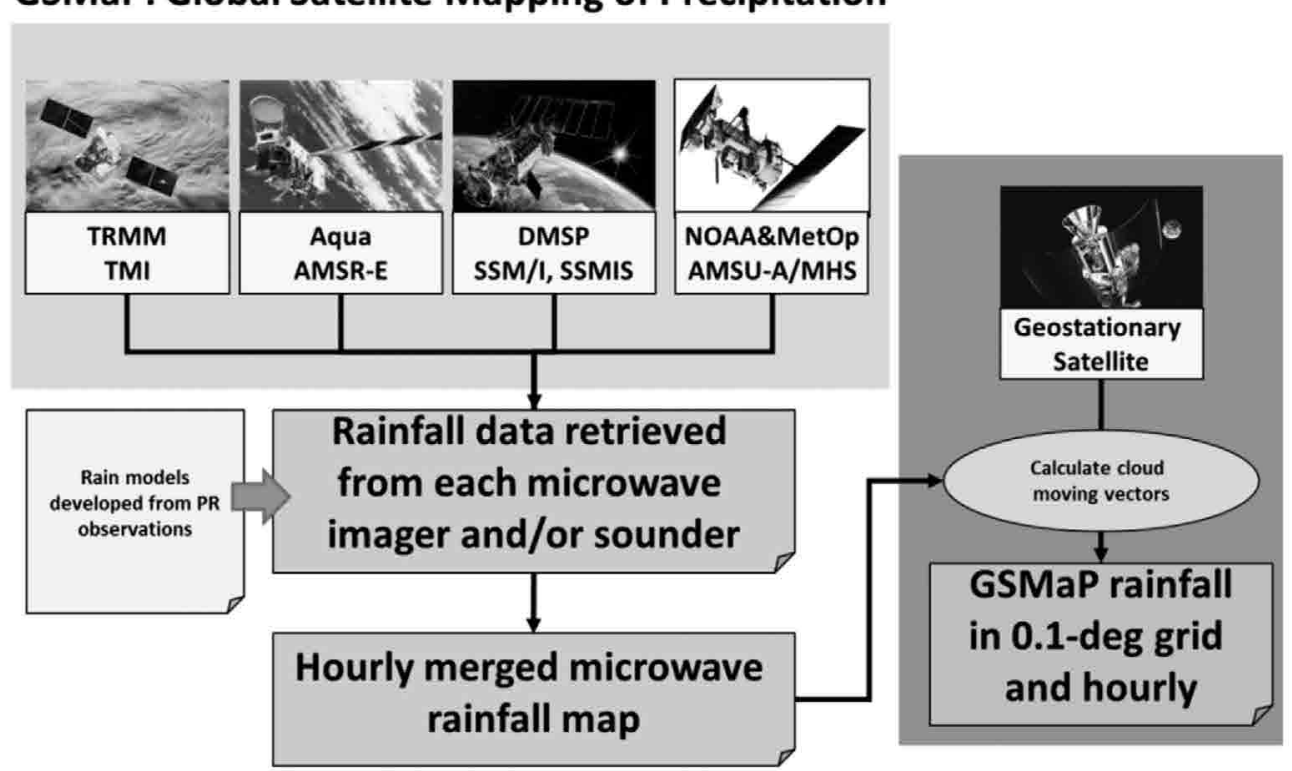

図 7 世界の雨分布速報（GSMaP：global satellite mapping of precipitation）の観測から全球降雨分布図 出力までの流れ図 出典 $\mathrm{JAXA}^{3)}$

AMSU, MetOp-A AMSU, GEO IR) を実質的にコ ンステレーションとして利用している(図 7 )。

物理量は降雨強度 $(\mathrm{mm} / \mathrm{h})$, 領域は全球（南緯・北
緯 $60^{\circ}$ 以内), 空間分解能緯度経度 0.1 度格子, 時間分解 能は 1 時間，表示時刻は世界標準時 (UTC) である。

GSMaP 全球降雨分布図（2014年 5 月16日01：00- 


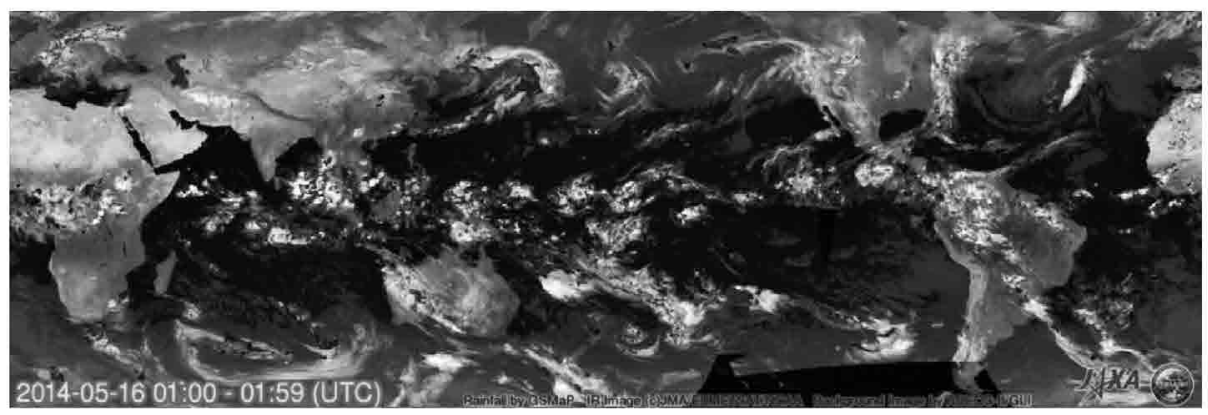

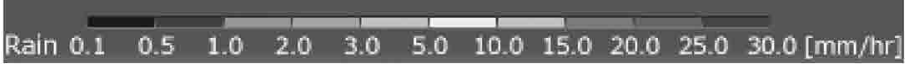

図 8 GSMaP 全球降雨分布図（観測時間：2014年 5 月 16 日01:00-01:59 (UTC))

準リアルタイムデータ利用ユーザ登録：http://sharaku.eorc.jaxa.jp/GSMaP/index_j.htm

01：59 (UTC) 観測) を図 8 に示す。分布図下のカラー バーが降雨強度 $(\mathrm{mm} / \mathrm{h})$ を表している。

背景の雲画像には, NOAA 気候予測センター (CPC)の作成による全球雲データを利用している。こ のデータは, 気象庁の静止気象衛星ひまわり (MTSAT), NOAA の静止気象衛星 GOES, EUMETSATの静止気象衛星 Meteosat の赤外 (IR) 情報を利 用している。アルゴリズムの開発・改良は, JAXA, 気 象庁気象研究所, 京都大学大学院理学研究科, 大阪大 学電気電子情報工学科, 東京大学大気海洋研究所が進 め，国際降水ワーキンググループが検証している。

\section{7.おわりに}

降水観測は気象観測の一部であるが, 従来から気象 観測の主流である可視光から熱赤外までの光学画像セ ンサ，赤外サウンダ，マイクロ波放射計，マイクロ波 サウンダなどの受動型センサに，能動型センサである レーダを加えたセンサ群による, 高精度の降水観測の 時代が到来したといえる。

GPM 計画により，GPM コンステレーションによる 高頻度かつ高精度の全球観測が 3 時間ごとに可能とな る。これによって長期及び短期の気象予報精度の向上,
河川管理及び農業用水などの水資源管理，気候变動 データの利用がさらに進み, 災害の早期警報・減災や 水・エネルギー・物質循環と生態系の地域規模の過 程 2 , 3)を解明し, 知識べースの適応・緩和策に役立つこ とが期待される。

(受付日2014.5.20, 受理日2014.5.30)

\section{参考文献}

1 ) 岡本謙一, 川田剛之, 熊谷 博, 五十嵐保, 浦塚 清峰, 宇宙工学シリーズ 9, 宇宙からのリモートセ ンシング，コロナ社，pp.109-240，2009年10月.

2 ) HarvestChoice, 2010. "Rainfall Variability and Crop Yield Potential.” International Food Policy Research Institute, Washington, DC., and University of Minnesota, St. Paul, MN.

http://harvestchoice.org/node/2240

3 ) Tamotsu IGARASHI : Japanese Programs on Space and Water Applications, COPUOS 2006, Vienna International Centre, June 2006.

http://www.oosa.unvienna.org/pdf/pres/copuos 2006/19.pdf 